\title{
Effect of Kinetin (6-FAP) and Cycocel (CCC) on Growth, Metabolism and Cellular Organelles in Pearl Millet (Pennisetum glaucum) Under Water Stress
}

\author{
Santosh Kumari* \\ Division of Plant Physiology, Indian Agricultural Research Institute, New Delhi-110012, India \\ *Corresponding author
}

A B S T R A C T

\begin{tabular}{|c|}
\hline Keywords \\
\hline $\begin{array}{l}\text { Cytokinins, } \\
\text { Chloroplast, } \\
\text { Furfuryl amino } \\
\text { purine osmotic } \\
\text { potential, Pearl } \\
\text { millet, Stomatal } \\
\text { conductance. }\end{array}$ \\
\hline Article Info \\
\hline $\begin{array}{l}\text { Accepted: } \\
\text { 23 June } 2017 \\
\text { Available Online } \\
10 \text { August } 2017\end{array}$ \\
\hline
\end{tabular}

The cytokinin production and transport from root to leaves is hindered under water stress causing leaf senescence due to the synthesis of hydrolytic enzymes. A part of stress effect may be linked to the regulation of osmotic solutes and maintenance of turgidity for stomatal conductance, photosynthesis and protein synthesis accompanied with reduced peroxidation of chloroplast and mitochondrial membranes in pearl millet under kinetin and cycocel treatments.

\section{Introduction}

Pearl millet has the potential to provide food and nutritional security as well as ensure sustainability for the poor farmers and fragile ecosystems with poor resource base. The coarse grain deserves investment in infrastructure, research, extension and industrial promotion.

The coarse grains are dual purpose nutritive crop (mineral matters, calcium and phosphorus is specifically high) and nutritional quality of stower is better than rice and wheat. Water stress impairs water relations, stomatal conductance, photosynthesis, respiration, carbohydrates, amino acids, protein metabolism and synthesis of plant hormones (Lockhart 1965, Hsiao 1973). Seed treatments and foliar application of plant growth regulators had been shown to improve these physiological and biochemical indices under water stress. The declining trend in the area under the crop also makes it imperative that productivity increase has to be given additional emphasis by striving for breakthrough in technology in research. The cereal is likely to become the food of the elite classes when industry is able to successfully exploit the diversified uses. Therefore, the study was undertaken to understand the effect of kinetin and cycocel 
on growth, metabolism and cellular organelles of pearl millet under water stress.

\section{Materials and Methods}

Plants were raised in thoroughly washed river sand by sowing five seeds of pearl millet, Pennisetum glaucum L. HHB-45 in earthen pots (size $30 \times 30 \mathrm{~cm}$ ) containing $5 \mathrm{~kg}$ sand. The experimental design was a completely randomized block. After emergence of seedlings, single plant was maintained in each pot. Each pot was supplied with $250 \mathrm{ml}$ of complete nutrient solution (Went 1957) and the iron source was used according to Arnon and Hoagland (1940) at weekly intervals. The plants were sprayed, at 20 days after seedling establishment, with0.25 $\mathrm{mM}$ and $0.50 \mathrm{mM}$ Kinetin (6- Furfuryl amino purine -FAP) and $30 \mathrm{Mm}$ and $60 \mathrm{mM}$ Cycocel (CCC) after testing under normal conditions in preliminary experiments. Plants were watered regularly. A group of 30 plants was subjected to water stress (ST) by restricting irrigation for three days at flowering (70 DAS). Half of the stressed plants were watered to attain normal turgidity and these were analysed after four days of revival of moisture conditions (REV). One group of plants, considered as control, received the normal irrigation schedule (UST) during the entire growing period. Plant height, root length, leaf number and fresh mass of various components were recorded for five plants under control conditions from each treatment and data has been expressed on per plant basis. Leaf area was recorded with leaf area meter (Li-3000). Relative water contents were determined following Weatherly and Slatyer (1957). Water potential of leaves was determined by pressure bomb technique, model 3005 plant water status console (Soil Moisture Equipment Corporation, USA). Osmotic potential was determined by psychrometric technique using 5100-B vapour pressure Osmometer (Wescor Inc. Logan, Utah, USA).
Tissues were killed according to the method of Walter and Kneeb (1970). Diffusive resistance meter (Li-60) was used to measure stomatal conductance. Photosynthetic and respiration rates were measured using InfraRed Gas Analyzer (ADC Type 225/2x, England). The time taken for $10 \mathrm{ppm}$ and 5 ppm changes in $\mathrm{CO}_{2}$ concentration was recorded, respectively. Total soluble carbohydrates were measured following Yemm and Willis (1954), free proline, protein estimation following Bates et al., (1973) and Lowry et al., (1951), respectively. Invertase (Acid), amylase and peroxidase activities were measured according to Sumner (1935), Shuster and Gifford (1962) and Seevers et al., (1971).Extraction medium for enzymes extraction contained $0.1 \mathrm{M}$ Tris- $\mathrm{HCl}$ buffer $\mathrm{pH} 7.4 ; 0.25 \mathrm{mM}$ EDTA, 2.5\% PVP and 2.5\% cysteine. $250 \mathrm{mg}$ of fresh leaves (Flag Leaves) were homogenized in a chilled glass mortar with a pestle using acid washed sand as abrasive. The homogenate was centrifuged at $10,000 \mathrm{~g}$ for $20 \mathrm{~min}$ at $4^{\circ} \mathrm{C}$ in a refrigerated centrifuge. The supernatant was used for enzyme activity and protein estimation. Protease activity was measured following hydrolysis of $1 \%$ casein prepared in $0.2 \mathrm{M}$ phosphate buffer ( $\mathrm{pH} 7.0), 1 \mathrm{ml}$ water and $1 \mathrm{ml}$ enzyme extract incubated at $40^{\circ} \mathrm{C}$ for $90 \mathrm{~min}$. The mixture was terminated by addition of $1 \mathrm{ml}$ of cold $20 \%$ TCA. The contents were kept in the cold for about $1 \mathrm{~h}$ and then centrifuged at $300 \mathrm{~g}$ for $15 \mathrm{~min}$. Amino acids ( $\mu \mathrm{g}$ amino acids per $\mathrm{mg}$ protein) liberated were estimated by method of Yemm and Cocking (1955).

\section{Results and Discussion}

Kinetin $(0.50 \mathrm{mM})$ increased plant growth in terms of stem length (Table 1) and leaf expansion while reduction in plant height contributed to increase in leaf area in CCC treatments. Low concentration of CCC further increased leaf area than high concentration 
accompanied with reduction in plant height and fresh mass. Root length was decreased in proportion to the stem height in both treatments. Low concentration of kinetin $(0.25 \mathrm{mM})$ significantly reduced plant growth. Root fresh mass was reduced or increased in proportion to root length in both treatments (Table 1) under normal growth environment in pot culture.

The reduction in plant height was apparent at higher concentration of cycocel. The reduction in apex elongation with retardant sprays was due entirely to a reduction of their internode distance on the stem and primordial distance on the apex. However, the reduction in cell enlargement is usually the first observable symptom of water stress and main cause of stunting. Shoot elongation by cytokinin was hardly influenced under water stress than control plants. The elongation may be due to stimulation of primordial production and partially to intermodal elongation on the apex. Hence cytokinin transported to the shoot may be of prime importance in maintaining normal growth by a direct effect on shoot growth or by exerting an effect through other hormones such as auxin, ethylene and gibberellins. It was interesting to note that both the concentrations of cycocel produced extensive root system and increased root/shoot which frequently proved effective in increasing yield under moisture stress conditions and decreasing lodging under excessive vegetative growth (Witwer and Tolbert, 1960; Cathey, 1964).The depressing action of FAP on root growth agreed with observations (Sprent, 1968) in rooting of shoots. Water stress led to the wilting and eventually to death of lower leaves possibly due to the injury and cessation of root growth at flowering stage (visual observation).

FAP $(0.50 \mathrm{mM})$ promoted leaf expansion while CCC (30 mM) maintained leaf number of control plants and increased leaf area. The finding showed that individual leaf size was affected by retardant treatments. Cycocel treatments increased cytokinins levels reported by Youssef and Abd El-Aal (2013) and those increased cell division creating more number of palisade cells; xylem and phloem tissue and leaf thickness.

Our study revealed that structural and functional components of mitochondria and chloroplast (Fig. 1 A, B, C, D) were impaired under water stress conditions and result in decline of photosynthetic and respiratory rates (Table 2). FAP and CCC reduced invertase activity and increased rate of photosynthesis in pearl millet leaves under normal and water stress environment, indicating reduced utilization of starch in root growth; internode growth and leaf expansion, respectively. An accumulation of starch following increased activity of starch synthesizing enzymes with cytokinins treatments had been reported in some plant organs (Smith and Palmer, 1970). Higher respiration rates in pearl millet leaves treated with higher doses of kinetin and cycocel was a result of higher availability of substrates and protective effect of these chemical on mitochondrial structure and outer membrane of chloroplast and formation of peripheral reticulum (Fig. 1 D) which led to increased surface area of chloroplast and interaction with mitochondria. This study has shown that peroxidation of membrane lipids resulted in hydrogen peroxide accumulation in cytoplasmic vacuoles and apoplastic region (space between cell wall and plasma membrane) under water stress conditions in pearl millet (Fig. $1 \mathrm{E}, \mathrm{F}$ ).

Higher contents of total starch, total soluble protein and total soluble sugars are attributable to low activity of carbon sink i.e. reduced internode length in CCC treatments and root growth inhibition with cytokinin treatments. Total soluble proteins and total starch were hydrolyzed resulting in upsurge in 
free proline, free amino acids and total soluble sugars, respectively, under water stress conditions in all treatments. Kinetin spray treatments exhibited delayed senescence of chloroplast envelope (Fig. 1C) and reduced protease and amylase activity.
However, CCC treatments stimulated translocation of total soluble sugars and free amino acids (Table 3) under water stress induced senescence (Fig.1B) in pearl millet leaves.

Table.1 Effect of kinetin and cycocel on growth parameters of pearl millet (70 DAS-Flowering) under natural growth conditions

\begin{tabular}{|l|l|l|l|l|}
\hline Treatments & $\begin{array}{l}\text { Stem height }(\mathrm{cm}) \\
\text { \& Fresh mass }(\mathrm{g})\end{array}$ & $\begin{array}{l}\text { Root length }(\mathrm{cm}) \\
\text { \&Fresh mass }(\mathrm{g})\end{array}$ & Root: shoot & $\begin{array}{l}\text { Leaf number \& } \\
\text { Leaf Area }\left(\mathrm{cm}^{2}\right)\end{array}$ \\
\hline Control & $120(31)$ & $62(16)$ & 0.52 & $13(599)$ \\
\hline $0.25 \mathrm{mM} \mathrm{FAP}$ & $118(30)$ & $58(13)$ & 0.49 & $12(603)$ \\
\hline $0.50 \mathrm{mM} \mathrm{FAP}$ & $125(39)$ & $63(17)$ & 0.50 & $13(641)$ \\
\hline $30 \mathrm{mM} \mathrm{CCC}$ & $118(28)$ & $62(15)$ & 0.53 & $13(618)$ \\
\hline $60 \mathrm{mM} \mathrm{CCC}$ & $110(24)$ & $58(14)$ & 0.53 & $13(609)$ \\
\hline C. D. at 5\% & $0.60(0.89)$ & $0.50(0.92)$ & $\mathrm{ns}$ & $1.0(1.20)$ \\
\hline
\end{tabular}

Table.2 Effect of kinetin and cycocel on water status indices, photosynthesis, respiration, Diffusive resistance of pearl millet under water stress

\begin{tabular}{|c|c|c|c|c|c|c|}
\hline Treatments & $\begin{array}{l}\text { Water } \\
\text { potential } \\
\text { (-MPa) }\end{array}$ & $\begin{array}{l}\text { Osmotic } \\
\text { potential } \\
\text { (-MPa) }\end{array}$ & $\begin{array}{l}\text { Relative water } \\
\text { contents }(\%)\end{array}$ & $\begin{array}{l}\text { Photosynthesis } \\
\mu \mathrm{mCO}_{2} \mathrm{~m}^{-2} \mathrm{~s}^{-1}\end{array}$ & $\begin{array}{l}\text { Respiration } \\
\mu \mathrm{mCO}_{2} \mathrm{~m}^{-2} \mathrm{~s}^{-1}\end{array}$ & $\begin{array}{l}\text { Diffusive } \\
\text { resistance } \\
\left(\text { Sec } \mathrm{cm}^{-1}\right)\end{array}$ \\
\hline \multicolumn{7}{|c|}{70 DAS (Flowering) - UST } \\
\hline Control & -1.38 & -1.48 & 72.9 & 9.45 & 0.98 & 10.99 \\
\hline $0.25 \mathrm{mM}$ FAP & -1.32 & -1.43 & 74.7 & 9.58 & 0.98 & 9.83 \\
\hline $0.50 \mathrm{mM}$ FAP & -1.30 & -1.53 & 82.9 & 10.33 & 1.04 & 8.66 \\
\hline $30 \mathrm{mM} \mathrm{CCC}$ & -1.28 & -1.63 & 80.3 & 9.88 & 0.95 & 9.80 \\
\hline $60 \mathrm{mM} \mathrm{CCC}$ & -1.34 & -1.45 & 73.9 & 10.33 & 1.04 & 9.55 \\
\hline \multicolumn{7}{|c|}{ ST } \\
\hline Control & -3.12 & -2.24 & 43.4 & 0.00 & 0.19 & 35.31 \\
\hline 0.25 mM FAP & -3.08 & -2.33 & 45.5 & 3.19 & 0.18 & 33.03 \\
\hline $0.50 \mathrm{mM}$ FAP & -3.02 & -2.42 & 61.7 & 3.53 & 0.25 & 25.00 \\
\hline $30 \mathrm{mM} \mathrm{CCC}$ & -1.98 & -2.63 & 56 & 3.34 & 0.19 & 35.56 \\
\hline \multirow[t]{2}{*}{$60 \mathrm{mM} \mathrm{CCC}$} & -3.04 & -2.31 & 49.5 & 3.59 & 0.29 & 34.22 \\
\hline & & & REV & & & \\
\hline Control & -1.52 & -1.41 & 66.2 & 2.27 & 0.83 & 14.98 \\
\hline $0.25 \mathrm{mM}$ FAP & -1.48 & -1.46 & 71.5 & 5.44 & 0.88 & 14.59 \\
\hline $0.50 \mathrm{mM}$ FAP & -1.36 & -1.78 & 74.3 & 5.73 & 0.90 & 12.02 \\
\hline $30 \mathrm{mM} \mathrm{CCC}$ & -1.44 & -1.84 & 77.5 & 4.36 & 0.87 & 14.28 \\
\hline $60 \mathrm{mM} \mathrm{CCC}$ & -1.39 & -1.43 & 72.2 & 5.79 & 0.91 & 13.99 \\
\hline $\begin{array}{l}\text { C. D. at 5\% } \\
\text { Chemical } \\
\text { ST } \\
\text { Chemical x ST }\end{array}$ & $\begin{array}{l}0.02 \\
0.01 \\
0.03\end{array}$ & $\begin{array}{l}0.01 \\
0.01 \\
0.03 \\
\end{array}$ & $\begin{array}{l}0.38 \\
0.29 \\
0.66 \\
\end{array}$ & $\begin{array}{l}0.08 \\
0.06 \\
0.14 \\
\end{array}$ & $\begin{array}{l}0.02 \\
0.02 \\
0.03\end{array}$ & $\begin{array}{l}0.43 \\
0.34 \\
0.76 \\
\end{array}$ \\
\hline
\end{tabular}


Table.3 Effect of kinetin and cycocel on metabolic indices of pearl millet leaves under water stress

\begin{tabular}{|c|c|c|c|c|c|}
\hline Treatments & 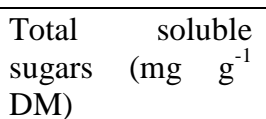 & $\begin{array}{l}\text { Total Starch } \\
\left(\mathrm{mg} \mathrm{g}^{-1} \mathrm{DM}\right)\end{array}$ & $\begin{array}{l}\text { Total Protein } \\
\left(\mathrm{mg} \mathrm{g}^{-1} \mathrm{DM}\right)\end{array}$ & $\begin{array}{l}\text { Proline } \\
\left(\mu \mathrm{g} \mathrm{g}^{-1} \mathrm{DM}\right)\end{array}$ & $\begin{array}{l}\text { Total free amino } \\
\text { acids } \quad\left(\begin{array}{ll}\mathrm{mg} & \mathrm{g}^{-1} \\
\mathrm{DM})\end{array}\right.\end{array}$ \\
\hline \multicolumn{6}{|c|}{70 DAS (Flowering) - UST } \\
\hline Control & 11.50 & 9.80 & 15.19 & 353 & 17.48 \\
\hline $0.25 \mathrm{mM}$ FAP & 14.30 & 10.77 & 15.58 & 272 & 13.24 \\
\hline $0.50 \mathrm{mM}$ FAP & 12.09 & 11.14 & 20.83 & 265 & 11.04 \\
\hline $30 \mathrm{mM} \mathrm{CCC}$ & 7.56 & 13.91 & 16.10 & 316 & 13.73 \\
\hline $60 \mathrm{mM} \mathrm{CCC}$ & 16.64 & 12.55 & 20.16 & 308 & 13.23 \\
\hline \multicolumn{6}{|c|}{ ST } \\
\hline Control & 15.18 & 6.95 & 8.18 & 5701 & 37.40 \\
\hline $0.25 \mathrm{mM}$ FAP & 16.80 & 9.56 & 9.38 & 1853 & 31.04 \\
\hline $0.50 \mathrm{mM}$ FAP & 15.20 & 10.38 & 10.56 & 1753 & 27.48 \\
\hline $30 \mathrm{mM} \mathrm{CCC}$ & 16.91 & 11.17 & 8.91 & 3763 & 32.36 \\
\hline $60 \mathrm{mM} \mathrm{CCC}$ & 18.17 & 10.50 & 9.42 & 2054 & 31.34 \\
\hline \multicolumn{6}{|c|}{ REV } \\
\hline Control & 5.86 & 8.77 & 9.09 & 856 & 29.31 \\
\hline $0.25 \mathrm{mM}$ FAP & 8.71 & 10.43 & 15.23 & 699 & 19.96 \\
\hline $0.50 \mathrm{mM}$ FAP & 6.63 & 11.08 & 16.59 & 534 & 17.65 \\
\hline $30 \mathrm{mM} \mathrm{CCC}$ & 5.02 & 11.36 & 12.59 & 746 & 21.21 \\
\hline $60 \mathrm{mM} \mathrm{CCC}$ & 6.60 & 11.00 & 16.25 & 593 & 20.21 \\
\hline C. D. at $5 \%$ & & & & & \\
\hline Chemical & 0.39 & 0.68 & 0.33 & 73.61 & 0.42 \\
\hline & 0.30 & 0.52 & 0.26 & 57.02 & 0.32 \\
\hline Chemical x ST & 0.69 & 1.18 & 0.58 & 127.50 & 0.73 \\
\hline
\end{tabular}

Table.4 Effect of kinetin and cycocel on invertase, amylase, protease and peroxidase activity of pearl millet leaves under water stress

\begin{tabular}{|c|c|c|c|c|}
\hline Treatments & $\begin{array}{c}\text { Invertase } \\
\mu \mathrm{g} \text { reducing sugars } \\
\mathrm{mg}^{-1} \text { protein } 30 \mathrm{~min}^{-1}\end{array}$ & $\begin{array}{c}\alpha \text {-Amylase } \\
\Delta \text { O.D. min }{ }^{-1} \mathrm{mg}^{-1} \\
\text { protein }\end{array}$ & $\begin{array}{c}\text { Protease } \\
\mu \mathrm{g} \text { amino acids } \mathrm{mg}^{-1} \\
\text { protein } 90 \mathrm{~min}^{-1}\end{array}$ & $\begin{array}{c}\text { Peroxidase } \\
\Delta \text { O.D. } 430 \text { min }^{-1} \mathrm{mg}^{-1} \\
\text { protein }\end{array}$ \\
\hline \multicolumn{5}{|c|}{70 DAS (Flowering) - UST } \\
\hline Control & 110 & 0.09 & 2.80 & 0.40 \\
\hline $0.25 \mathrm{mM}$ FAP & 105 & 0.07 & 1.80 & 0.49 \\
\hline $0.50 \mathrm{mM}$ FAP & 85 & 0.05 & 1.65 & 0.50 \\
\hline $30 \mathrm{mM} \mathrm{CCC}$ & 90 & 0.08 & 2.80 & 0.39 \\
\hline $60 \mathrm{mM} \mathrm{CCC}$ & 102 & 0.05 & 1.70 & 0.49 \\
\hline \multicolumn{5}{|c|}{ ST } \\
\hline Control & 90 & 0.12 & 15.50 & 0.59 \\
\hline $0.25 \mathrm{mM}$ FAP & 42 & 0.12 & 14.00 & 0.91 \\
\hline $0.50 \mathrm{mM}$ FAP & 75 & 0.13 & 11.95 & 0.61 \\
\hline $30 \mathrm{mM} \mathrm{CCC}$ & 40 & 0.11 & 13.00 & 0.80 \\
\hline $60 \mathrm{mM} \mathrm{CCC}$ & 70 & 0.09 & 12.00 & 0.90 \\
\hline \multicolumn{5}{|c|}{ REV } \\
\hline Control & 95 & 0.11 & 10.50 & 0.50 \\
\hline $0.25 \mathrm{mM}$ FAP & 80 & 0.11 & 5.50 & 0.59 \\
\hline $0.50 \mathrm{mM}$ FAP & 93 & 0.11 & 3.90 & 0.61 \\
\hline $30 \mathrm{mM} \mathrm{CCC}$ & 83 & 0.10 & 4.50 & 0.55 \\
\hline $60 \mathrm{mM} \mathrm{CCC}$ & 90 & 0.07 & 3.50 & 0.58 \\
\hline \multicolumn{5}{|l|}{ C. D. at $5 \%$} \\
\hline Chemical & 05 & 0.02 & 0.15 & 0.01 \\
\hline ST & 02 & 0.01 & 0.50 & 0.01 \\
\hline Chemical x ST & 03 & 0.01 & 0.50 & 0.01 \\
\hline
\end{tabular}


Fig.1 Effect of cytokinin on chloroplast and mitochondrial membranes and hydrogen peroxide accumulation in cytoplasmic and apoplastic region in mesophyll tissue of pearl millet under water stress condition

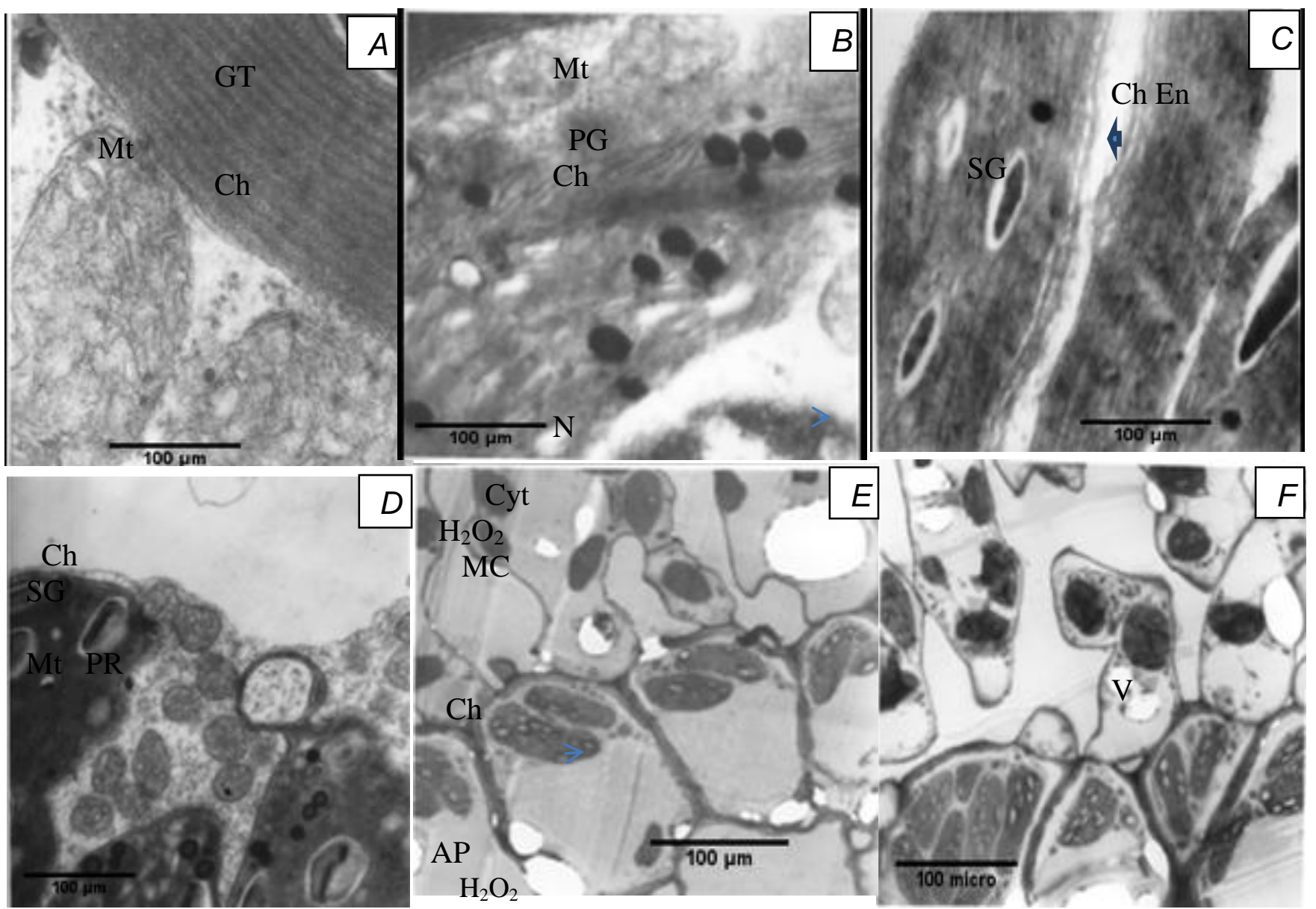

Higher contents of total soluble sugars, proline and free amino acids revealed their association with osmotic adjustment and lower osmotic potential in cycocel treated leaves with lower water potential in pearl millet. Therefore, these leaves retained higher relative water contents and appeared least affected under water stress and after revival of water stress conditions (Table 2). Stomatal conductance soared with higher concentrations of kinetin and cycocel treatments under control conditions which correspond to higher water potential. Therefore, water availability to the photosynthetic machinery and higher light interception by larger leaves affected the rate of photosynthesis in these treatments. Low diffusion resistance (Henson et al., 1981 b) owing to better water potential/turgidity of tissue contributed in relatively higher photosynthetic rate, low respiration and starch accumulation in these treatments than leaves of control plants. Protease activity was remarkably increased under water stress conditions irrespective of treatments. Peroxidase activity upsurge may be a consequence of higher metabolic rate, production of hydrogen peroxide $\left(\mathrm{H}_{2} \mathrm{O}_{2}\right)$ and detectable rates of photosynthesis and respiration in growth regulators treated leaves under water stress.

Pearl millet plants suffered a negative turgor of leaf tissue at the end of the stress period 
and could not attain the pre-stressed values of water and osmotic potential within three days of rehydration. The study further revealed that FAP and CCC increased RWC and decreased osmotic potential. Plant growth regulators induced shift in osmotic pressure could have metabolic consequences and also support the higher fresh mass of plant components (Nekrasova, 1969) under water stress.

Cytokinin (BAP) together with cytokinin binding protein in the soluble state located on the surface of the chloroplast membrane system (Huang et al., 1990) which is known to enhance photophosphorylation in chloroplast, maintained outer membrane of chloroplast (Fig. 1 C, D). A major shift in metabolism under water stress involved appreciable increase in free amino acids, a dramatic rise in proline contents and a sharp increase in soluble carbohydrates. Reduction in total starch and protein was accompanied by an increase in hydrolytic enzymes i.e. amylase and protease An alteration in metabolism under cytokinin and cycocel treatments involved appreciable increase in starch, protein and a sharp rise in soluble sugars. However, CCC and FAP treatments depressed the free proline (Table 2). The low amounts of free proline clearly show remarkable effect of these growth regulators on cell membrane and cell wall integrity. Peroxidation of cell membrane and cell wall associated proteins, release this amino acid, therefore, proline concentration in pearl millet leaves serve as an index of injury/integrity. These treatments depressed the activity of hydrolytic enzymes i.e. amylase and protease along with free amino acids levels under water stress condition (Table 4). The stimulation in peroxidase activity decreased accumulation of hydrogen peroxide that tears cell wall and damage cytoplasmic organelles (mitochondria and chloroplast)in plant cells. Therefore, growth regulators decreased reactive oxygen species and enhanced the activity of this antioxidant enzyme (Asada and Badger, 1984). The dismutation of superoxide radicals into $\mathrm{H}_{2} \mathrm{O}_{2}$ and oxygen is an important step in the cell defense. Peroxidase is localized in cell vacuole, cell wall and cytoplasm (Asada, 1992) and is important in scavenging $\mathrm{H}_{2} \mathrm{O}_{2}$. The disruption of normal mitochondrial and chloroplast electron flow could result in oxidative stress and greater production of reactive oxygen species including $\mathrm{H}_{2} \mathrm{O}_{2}$ under water stress conditions. Besides, these factors, water stress reduced source strength by reducing photosynthesis as well as leaf area (leaf death) and reduced sink strength by inhibiting growth, thus lessening translocation of metabolites and ultimately the final yield (Wardlaw 1969; Crafts and Crisp, 1971).

High rates of photosynthesis, lower rates of respiration and a higher root/shoot characterize hardened plants (May and Milthorpe, 1962). The higher leaf area intercepts more radiations result in increased assimilates and shoots biomass. On the other hand higher transpiration from larger photosynthetic surface result in quick water loss and abscisic acid biosynthesis under water stress conditions. Our result exhibit that cytokinin and cycocel facilitated stomatal opening and diffusion of water vapour and $\mathrm{CO}_{2}$ resulting in detection of photosynthetic rate in pearl millet leaves.

In conclusion progressive senescence and death of leaves from the basal portion acropetally on a shoot are common in most plants that are accentuated by water stress. Cycocel induced cytokinins and kinetin delayed cytological changes structural and functional disorganization of organelles (chloroplast and mitochondria), membrane peroxidation, destruction of protein synthesizing machinery and eventual breakdown of nuclei leading to cell death, in pearl millet leaves under water stress. The 
major sinks for the cytokinins are parts of the plants such as young leaves, internodes, developing panicle, and seeds that have growth potential and are centers of cytokinin production together with root tips. Higher cell division along with stimulated assimilates translocation cause bold seeds and higher seed test weight result in increased production in pearl millet. It is, therefore, conceivable that these growth regulators could change the growth responses to water stress by means of 1) modification of the rate of water uptake by changing the plant root/shoot 2) changes in the rate of water loss from the leaf surface and 3 ) the changes in the balance of forces affecting the water within the plant cells.

\section{References}

Arnon, D.I. and Hoagland, D.R. 1940. Crop production in artificial culture solutions and soils with special reference to factors affecting yields and absorption of inorganic nutrients. Soil Sci., 50: 463-485.

Asada, K. 1992. Ascorbate peroxidase-a hydrogen peroxide-scavenging enzyme in plants. Physiol. Pl., 85: 235-241.

Asada, K. and Badger, M.R. 1984. Photoreduction of $18 \mathrm{O}_{2}$ and $\mathrm{H}_{2} 18 \mathrm{O}_{2}$ with concomitant evolution of $16 \mathrm{O}_{2}$ in intact spinach chloroplasts: Evidence for scavenging of hydrogen peroxide by peroxidase.Pl. Cell Physiol., 25: 11691179 .

Bates, L.S., Waldren, R.P. and Teare, L.D. 1973. Rapid determination of free proline for water stress studies. Pl. Soil, 39: 205-207.

Cathey, H.M. 1964. Physiology of growth retarding chemicals. Ann. Rev. Pl. Physiol. 15: 271-299.

Chinoy, J.J.1960. Physiology of drought tolerance in wheat. I. Effect of wilting at different stages of growth on survival values of eight varieties of wheat belonging to seven species. Phyton, 14: 147-157.

Crafts, A.S. and Crisp, C.E. 1971. Phloem transport in plants (Eds: D. Kennedy and R. B. Park) W. H. Freeman and Comp., San Francisco.

Hsiao, T.C. 1973. Plant responses to water stress. Ann. Rev. Pl. Physiol., 24: 519570.

Henson, I.E., Mahalakshmi, V., Alagarswamy, G. and Bidinger, F.R.1981.b an association between flowering and reduced stomatal sensitivity to water stress in pearl millet [Pennisetum americanum (L.) Leeke].Annals Bot., 52(5): 641-648.

Huang, et al., 1990. Plant Membranes: A biophysical approach to structure, development and senescence (Leshem Y.Y.)https://books.google.co.in/books?i sbn $=9401726833$

Lockhart, J.A. 1965. An analysis of irreversible plant cell elongation. $J$ Theor Biol., 8(2): 264-275.

Lowry, O.H., Rosebrough, N.J., Lewis Farr, A. and Randall, R.J. 1951. Protein measurement with the folin phenol reagent. J. Biol. Chem., 28: 265-275.

May, L.H. and Milthorpe, F.L. 1962. Drought resistance of crop plants. $\mathrm{Fl}$. Crop Abstr, 15: 171-180.

Nekrasova T.N. 1969. Effect of retardant CCC on morphogenesis of fruit tree samplings. Sov.Pl. Physiol., 16: 238244.

Seevers, P.M., Daly, J.M. and Catedral, F.F. 1971. The role of peroxidase isoenzymes in resistance to wheat stem rust disease. Pl. Physiol., 48: 353- 360.

Smith, O.E. and Palmer, C.E. 1970. Cytokinin induced tuber formation on stolon of Solanum tuberosum. Physiol. Plant., 23: 599-606.

Sprent, J.I. 1968. Effects of Benzyl adenine on cotyledon metabolism and growth of peas. Planta, 81: 80-87. 
Sumner, J.B. 1935. A more specific reagent for determination of sugar in urine. $J$. Biol. Chem., 69:363.

Tolbert, N.E. 1960. 2-Chloroethyl trimethyl ammonium chloride and related compounds as plant growth substances. II. Effect on growth of wheat. Pl. Physiol., 35: 380-385.

Wardlaw, I.F. 1969. The effect of water stress on translocation in relation to photosynthesis and growth. II. Effect during leaf development in Lolium temulentum L. Australian J. Biol. Sci., 22: $1-16$.

Walter, H. and Kneeb, K. 1970. Protoplasmotologia (II, C-6), pp. 125135 Springer Verlag, Berlin-New York.

Weatherly, P.E. and Slatyer, R.O.1957. Relationship between relative turgidity and diffusion pressure deficit in plants. Nature, 179: 1085-1086.

Went, F.W. 1957. The experimental control of plant growth. Pp.77-93. the Ronald Press Co., New York.

Witwer, S.H. and Tolbert, N.E. 1960. 2-
Chloroethyl trimethyl ammonium chloride and related compounds as plant growth substances. V. Growth, flowering and fruiting responses as related to those induced by auxin and GA. Pl. Physiol., 35: 871-877.

Yadava, R.B.R. and Patil, B.D. 1980. Effect of growth retardants on plant growth, yield and seed carbohydrates ofbajra. Forage Res., 6: 175-179.

Yemm, E.W. and Willis, A.J. 1954. The estimation of carbohydrates in plant extracts by anthrone. Biochem.J, 57: 508-514.

Yemm, E.W. and Cocking, E.C. 1955. The determination of amino acids with ninhydrin. Analyst, 80: 209-213.

Youssef, A.S.M. and Abd El Aal, M.M.M.2013.Effect of paclobutrazol and cycocel on growth, flowering, chemical composition and histological features of potted Tabernaemontana coronaria Stapf plant. J. Appl. Sci. Res., 9(11): 5953-5963.

\section{How to cite this article:}

Santosh Kumari. 2017. Effect of Kinetin (6-FAP) and Cycocel (CCC) on Growth, Metabolism and Cellular Organelles in Pearl Millet (Pennisetum glaucum) Under Water Stress. Int.J.Curr.Microbiol.App.Sci. 6(8): 2711-2719. doi: https://doi.org/10.20546/ijcmas.2017.608.325 